\title{
Erratum to: Manipulation and mitigation
}

\section{Andrew C. Khoury}

\section{Erratum to: Philos Stud \\ DOI 10.1007/s11098-013-0125-7}

The original version of this article unfortunately included an error in the final sentence of Sect. 4. The corrected sentence is given below.

And, as McKenna has argued with respect to the traditional manipulation argument, if this "plays out in a dialectical stalemate, this amounts to a victory for the compatibilist, since it is the incompatibilist who is presenting an argument" (2008, p. 148).

The online version of the original article can be found under doi:10.1007/s11098-013-0125-7.

A. C. Khoury $(\bowtie)$

Department of Philosophy, Logic, and Scientific Method, London School of Economics, London, UK

e-mail: andrewckhoury@gmail.com 